Phytopathol. Mediterr. (2001) 40, Supplement, S330-S335

\title{
Fungi associated with esca and young grapevine decline in Greece
}

\author{
Ionnis Rumbos and Artemis Rumbou
}

Nagref, Plant Protection Institute of Volos, P.O.Box 1303, 38001 Volos, Greece

\begin{abstract}
Summary. In the period 1998-2001 significant numbers of vine samples of different varieties, grafted onto different rootstocks, ready for out-planting or planted and declined a few months or years later, were collected or sent to our laboratory to investigate the presence of phytopathogenic fungi. Three hundred eighty rooted cuttings ready for outplanting, 1250 young vines planted and exhibiting decline symptoms in the first year of establishment, 82 vines two to nine years old and 27 old vines exhibiting the classical esca symptoms were examined. Isolations yielded the fungi Phaeomoniella chlamydospora, Fomitiporia punctata and Stereum hirsutum, as well as other fungi of the genera Phaeoacremonium, Cylindrocarpon and Botryosphaeria. The low incidence of these fungi isolated in a low percentage of samples suggested that they could not by themselves be the cause of young grapevine decline. Abiotic causes, such as lesions from improperly healed rootstock disbudding sites and graft unions made in the nursery, as well as improper storage and transportation conditions of the propagated material must also have played a role and made the decline more acute. The occurrence of the isolated fungi as endophytes and their role in the outbreak of grapevine decline remain to be investigated.
\end{abstract}

Key words: grapevine, esca, Phaeomoniella chlamydospora, Phaeoacremonium spp.

\section{Introduction}

For several decades, decline diseases have been reported in old Greek grapevines, resulting in reduced vigour and productivity and finally leading to the death of branches or whole vines. In recent years, the problem has become more prevalent in young grapevines and is now the reason of considerable concern, particularly for growers, who were already being hard hit by unsuccessful vineyard establishment. Another matter for concern is that sudden outbreaks of these diseases may result from

Corresponding author: I. Rumbos

Fax: +30 42168921

E-mail: instfyt@hol.gr contaminated or sub-standard grape propagation material imported into Greece.

Since 1998, the incidence of decline symptoms in young grapevines has been increased and the disease is becoming more frequent in Greece. Many growers report having to replant all or part of their young vineyards after poor early growth, resulting in significant economic losses from replanting costs. Similar losses are also reported from California where many growers have to replant vines in areas with poor vine establishment or where vines grow slowly (Whiting et al., 2001).

In Greece as in other countries (Mugnai et al., 1999), esca has been considered a simple disease of old vines associated with wounds and white rot of the trunk and the main branches (Rumbos, 1995). Growers keep the disease under control by 
sanitary practices such as the removal of affected vines and the protection of large pruning wounds. One of the oldest practices intended to reduce the symptoms of esca is to split the vine trunk and insert a stone in the crack.

Wood-rotting basidiomycetes such as Fomes igniarius, later renamed Phellinus igniarius (L. ex Fr.) Quelet, Fomitiporia punctata (Fr.) Murrill, and Stereum hirsutum (Wild) Fries are considered to be causal agents of esca. Zachos (1960) consistently isolated a Cephalosporium species from diseased vines cv. Korinthiaki exhibiting black or brown wood-streaking. These vines showed decline, wilting and death. Inoculation with this undetermined species of Cephalosporium into the wood of healthy 2, 3 and 4-year-old vines resulted 4 months later in dark brown striations extending $15-20 \mathrm{~cm}$ from the site of inoculation. Re-isolations from these dark areas yielded the same fungus.

In view of these findings, an extensive study was carried out in the main grape-growing areas of Greece in order to investigate the severity of the esca-decline problem and the identity of the fungi that were associated with infected grape propagation material imported into Greece.

\section{Materials and methods}

In the period 1998-2001, large numbers of diseased grapevine plants were collected or sent to our laboratory to identify the phytopathogenic fungi present. Four groups of vine material were examined: 380 rooted grafted plants ready for planting out, 1250 young vines that had exhibited decline symptoms in the first year of establishment, 82 two to nine-year-old vines and 27 older vines both of which had exhibited the classical esca symptoms. In addition, a sample consisting of unrooted cuttings of rootstocks $110 \mathrm{R}$ and SO4, coming from a heavily infected Greek nursery, was sent for examination.

Plants were washed with water and their roots were removed. Trunks were cut lengthways and crossways, and inspected for wood discoloration and other abnormalities. Small fragments of affected tissue (30 per vine), approximately $3 \times 2 \times 2 \mathrm{~mm}$ in size, were removed at the graft union and at the basal end of the rootstock of the one-year-old vines, and incubated on Petri dishes containing dextrosepotato-agar medium (three pieces per dish). In old vines isolations were made from the discolored area close to the pith. After one week of incubation in the dark at $25 \pm 1^{\circ} \mathrm{C}$, the fungi that developed were transferred to fresh medium for identification. Isolates were identified based on morphological and cultural characteristics (Barnett, 1960; Anonymous, 1964-2000). Phaeomoniella chlamydospora and Phaeoacremonium spp. were identified in accordance with the description of Crous et al. (1996) and Crous and Gams (2000).

\section{Results}

All 1630 rooted grafted vines and young vines exhibited wood discoloration. In cross-section this appeared as dark-brown spots (Fig. 1), often close to the pith, and in longitudinal view it showed up as dark-brown streaks along the vessel elements, especially at the basal end and near the graft union (Fig. 2). In 56\% of samples dark-brown streaks were observed at both the basal end of the rootstock and the graft union, in 37\% at the basal end, and in $7 \%$ only at the graft union. Scions and especially rootstocks that remained in the field for 6 18 months after planting also showed decreased trunk size. In some cases there were swellings and accumulation of assimilates at the graft union. Isolations for Agrobacterium tumefaciens were negative. Cases where the diameter of the swellings was twice the size of the scion were observed both in 1year-old plants from newly established vineyards and in grafted plants in the nursery sent to our laboratory. Here the incidence of infection was 25 and $42 \%$ respectively.

Graft-failure symptoms were also observed in plants sent to our laboratory. In these plants the graft union was dark and dark-brown streaks extended up or down from the graft, which was easily broken. Callusing was negatively affected (Fig. 3).

According to field observations, some vines suffered a sudden collapse, but more frequently there was slow withering and stunted growth in the first years after grafting. A reduced total root biomass and lower numbers of white feeder roots are commonly seen.

Symptoms on young (two to nine-year-old) grapevines included weak and stunted growth, with shorter internodes and small, sometimes chlorotic leaves. Some plants showed stronger decline symptoms and died. Older grapevines exhibited the 
classical chronic symptoms of esca, known as "white rot" (Fig. 4).

Isolations yielded a number of fungi (Table 1). Phaeomoniella chlamydospora, Phaeoacremonium spp., and Cylindrocarpon spp. were isolated from a small percentage (1-4\%) of plants mainly from the basal end of the rootstock and the graft union (Table
2). Fomitiporia punctata was isolated in a high percentage $(41.2 \%)$ of old grapevines that exhibited the classical esca symptom of white rot (Table 1). Unrooted cuttings of the rootstocks $110 \mathrm{R}$ and SO4 coming from a Greek nursery showed a very high incidence of severe wood discoloration. Isolations yielded a low incidence of pathogenic fungi (Table 2).

Table 1. Percentage of vines of different age from which each fungal species was isolated.

\begin{tabular}{|c|c|c|c|c|}
\hline \multirow{2}{*}{ Fungus } & \multicolumn{4}{|c|}{ Vine age $^{\mathrm{a}}$} \\
\hline & $\mathrm{V}_{1}$ & $\mathrm{~V}_{2}$ & $\mathrm{~V}_{3}$ & $\mathrm{~V}_{4}$ \\
\hline Alternaria spp. & 5.6 & 3.2 & 4.1 & 2.1 \\
\hline Aspergillus spp. & 6.4 & 2.3 & 3.3 & 1.1 \\
\hline Botryosphaeria spp. & 3.1 & 4.5 & 6.6 & 2.2 \\
\hline Cladosporium sp. & 1 & 0.3 & 0.9 & 1.3 \\
\hline Coniothyrium sp. & 1.4 & 1.1 & 0.3 & 0.6 \\
\hline Cylindrocarpon sp. & 1.2 & 1.4 & 0 & 0 \\
\hline Fomitiporia punctata & 0 & 0 & 4.2 & 41.2 \\
\hline Fusarium spp. & 11.1 & 7.3 & 6.2 & 1.2 \\
\hline Eutypa lata & 0 & 0 & 3.2 & 2.3 \\
\hline Penicillium spp. & 3.4 & 2.8 & 0.3 & 2.1 \\
\hline Phaeoacremonium spp. & 1.1 & 1 & 0.3 & 0 \\
\hline Phaeomoniella chlamydospora & 1.7 & 1.9 & 0.5 & 0 \\
\hline Phoma sp. & 0.9 & 0.6 & 0 & 0 \\
\hline Phomopsis sp. & 0.7 & 1.1 & 0 & 0 \\
\hline Sphaeropsis malorum & 7.3 & 6.8 & 3.3 & 1.5 \\
\hline Trichoderma spp. & 9.5 & 11.3 & 6.6 & 3.2 \\
\hline Mycelia sterilia & 18.2 & 25.1 & 11.4 & 12.8 \\
\hline Undetermined & 27.4 & 29.3 & 48.8 & 28.4 \\
\hline
\end{tabular}

${ }^{a} V_{1}=$ rooted plants ready for planting; $V_{2}=$ vines 6 to 18 month-old; $V_{3}=$ vines 2 to 9 years old, $V_{4}=$ vines $>10$ years old.

Table 2. Percentage of one-year-old grapevines of various cultivars and rootstocks showing severe wood discoloration.

\begin{tabular}{|c|c|c|c|c|c|c|}
\hline \multirow{2}{*}{$\begin{array}{l}\text { Cultivar or } \\
\text { rootstock }\end{array}$} & \multicolumn{2}{|c|}{$\begin{array}{l}\text { Phaeomoniella } \\
\text { chlamydospora }\end{array}$} & \multicolumn{2}{|c|}{$\begin{array}{l}\text { Phaeoacremonium } \\
\text { spp. }\end{array}$} & \multicolumn{2}{|c|}{$\begin{array}{l}\text { Botryosphaeria } \\
\text { spp. }\end{array}$} \\
\hline & Graft union & Basal end & Graft union & Basal end & Graft union & Basal end \\
\hline Agiorgitico & 1.1 & 1.8 & 1.6 & 2.5 & 4.2 & 5.8 \\
\hline Shiraz & 0.9 & 1.6 & 1.6 & 2.3 & 0.8 & 0.9 \\
\hline Roditis & 1.3 & 1.1 & 0.4 & 1.8 & 2.1 & 2 \\
\hline Moscat of Hamburg & 0.4 & 1.8 & 0.9 & 0.7 & 3 & 1.2 \\
\hline Korinthiaki & 0.8 & 1.2 & 1.6 & 1.9 & 0.5 & 0.9 \\
\hline Xinomavro & 0.4 & 0.8 & 1.5 & 2.5 & 1.2 & 1.3 \\
\hline Mavrodafni & 1.6 & 2.1 & 1.3 & 2.7 & 2.1 & 0.8 \\
\hline Victoria & 1.2 & 1.8 & 0.2 & 2.1 & 2.3 & 2.7 \\
\hline Cabernet Sauvignon & 0.9 & 1 & 0.4 & 2.3 & 1.6 & 1.2 \\
\hline $\mathrm{SO} 4$ & 1 & 1.5 & 1.7 & 2.2 & 0 & 0 \\
\hline 110Richter & 0.9 & 1.2 & 0.4 & 1.8 & 0.5 & 0.5 \\
\hline 1103 Paulsen & 2.1 & 2.7 & 0.7 & 1.9 & 1.2 & 0.5 \\
\hline $3309 \mathrm{C}$ & 1.8 & 2.1 & 0.8 & 2.1 & 0.3 & 0.8 \\
\hline 779 Paulsen & 0.4 & 0.8 & 0.3 & 0.8 & 1.0 & 0.8 \\
\hline
\end{tabular}




\section{Discussion}

In recent years, a decline of young grapevines has been reported in major grape-production regions of Greece. Affected vineyards show poor vine establishment in the first year and slow growth in subsequent years (Rumbos, 2000). In several cases, growers were forced to replant young vineyards, resulting in significant economic loss. The origin of the infection in these vines was hypothesized to be the nursery that produced the plants.

Isolations made in our laboratory from numerous young vines with decline symptoms yielded fungi of the genera Botryosphaeria, Phaeoacremonium, Cylindrocarpon, and the fungus Phaeomoniella chlamydospora. All these fungi are referred to in the literature as possible causal agents of decline.

Cases of dieback and decline of young grapevines attributed to $P$. chlamydospora and related fungi have been reported from most grape-growing regions worldwide, including South Africa (Ferreira et al., 1994), the United States of America (Morton, 1995; Scheck et al., 1998), Italy (Mugnai et al., 1996; 1999), Portugal (Chicau et al., 2000), Australia (Pascoe, 1999) and Turkey (Erkan Ari, 2000; Koklu, 2000). The anamorphic fungus $P$. chlamydospora (W. Gams, Crous, M.J. Wingf \& L. Mugnai) Crous \& W. Gams (syn. Phaeoacremonium chlamydosporum W. Gams, Crous, M.J. Wingf $\&$ L. Mugnai) is strongly suspected to be the causal agent of "black goo" ${ }^{(1)}$ grapevine disease, also known as "Petri grapevine decline" (Morton, 1997; Scheck et al., 1998; Ferreira et al., 1999). This same fungus is also associated with esca (Mugnai et al., 1996, 1999; Larignon and Dubos, 1997).

Contrary to expectations, P. chlamydospora was recovered in our tests at very low percentages. Similar results are reported from USA and Australia, where in one case the fungus occured in only two of thirty-two samples (Morton, 1999). In that study it was further stated that the fungus can be difficult to isolate even from vines known to be infected. However, similar fungi such as Cephalosporium sp. and Phialophora parasitica are frequently isolated in Greece from affected grapevines and

\footnotetext{
(1) At the General Assembly of the $2^{\text {nd }}$ ICGTD meeting held at Lisbon in 2001 it was unanimously decided that these diseases should henceforth be called Petri disease.
}

some fruit trees (Zachos, 1960; Rumbos, 1986). On the other hand, $P$. chlamydospora and Phaeoacremonium spp. have been isolated from apparently healthy vines and from rooted cuttings (Bertelli et al., 1998; Scheck et al., 1998), which means that these fungi can occur as endophytes or as latent infections in grapevine tissue. It has been suggested that they cause damage mainly in vines that are weakened by different stresses, such as water deficit, low temperature and early fruiting (Graniti et al., 2000; Whiting et al., 2001).

Botryosphaeria spp. were isolated from young (one to seven year-old) grapevines showing dark discoloured wood, poor shoot development and dead arm. In other hosts, such as pome fruits, peach, kiwifruit and walnut (Rumbos, 1987), it was shown that these fungi can invade wounds causing cankers. Similar findings were observed in this study in some declining young vines showing discoloured wood associated with pruning wounds, from which fungi of the genus Botryosphaeria were isolated. Recently, a new grapevine decline caused by $B$. obtusa and B. dothidea was reported from France (Larignon et al., 2001), which suggest the pathogenic character of these fungi.

Concerning the sources of inoculum, it has been hypothesized that the pathogenic fungi are present in the vine propagation material, either from the mother plants that already harboured them in latent form (Ferreira, 1999; Pascoe and Cottral, 2000), or by entering the cuttings through cuts and wounds that occurred during nursery processes (Bertelli et al., 1998; Scheck et al., 1998).

Since in the most cases both the incidence and the intensity of the brown discoloration were higher at the basal end of the plants, it can be hypothesized that the infection begins in the rootstock. Only in a few $(7 \%)$ ready-for-outplanting vines, which were characterized by symptoms of graft failure (the graft was easily broken) did the dark streaks extend on either side of the graft. Studies in Portugal on rootstock mother plants showed that most canes did not harbour these fungi (Rego et al., 2001). By contrast, similar studies in Australia showed that most rootstock mother vines were infected with $P$. chlamydospora. Tests on $V$. vinifera source material were positive and suggested that newly planted vines became infected through either the stock or the scion (Pascoe and Cottral, 2000).

It thus seems that the problem comes from nurs- 


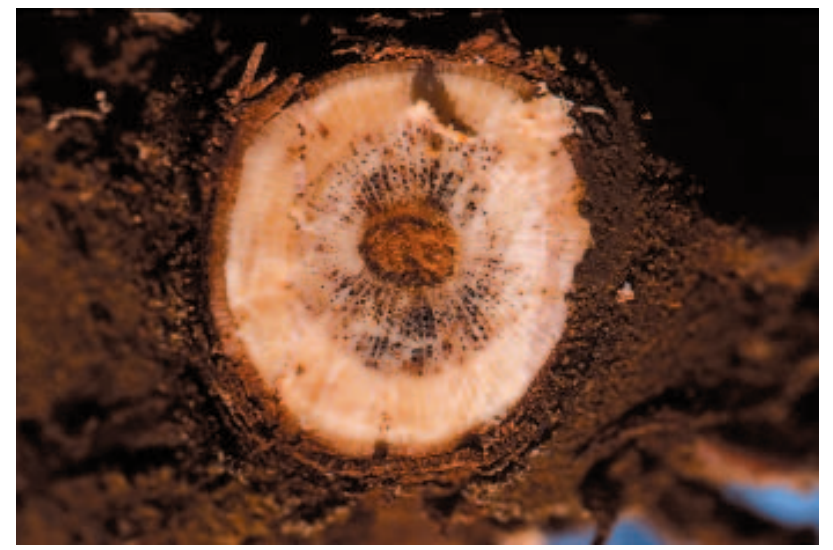

Fig. 1. Cross-section through the basal end of the rootstock stem of a 2-year-old infected grapevine (Syrah/ 3309 C) showing wood browning and black spots.

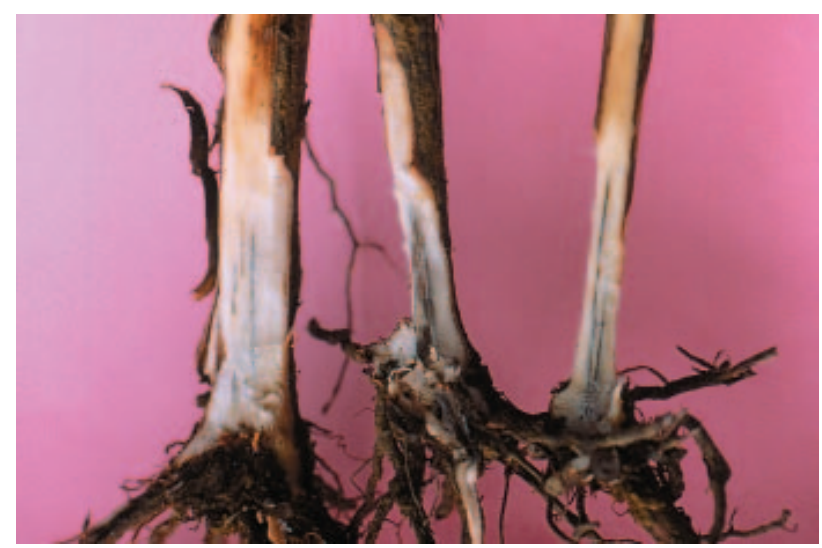

Fig. 3. Graft failure symptoms correlated with dark brown streaks extending up or down from the graft union.

eries, either through already infected material or through cuts made during preparation and storage processes. Transportation over long distances could increase the problem, as is the case in Greece, where much grapevine propagation material is imported from France, Italy and other countries.

In 2001, the samples examined included the heavily infected rootstocks SO4 and 110R (infection $>50 \%$ ). However, isolations from these rootstocks yielded only a low incidence of pathogenic fungi, which suggests that abiotic causes were responsible for infected propagation material. A survey is planned next year in Greek rootstock nurseries on both cuttings coming directly from mother plants and rooted cuttings ready for distribution.

The only unquestionable result of this study is

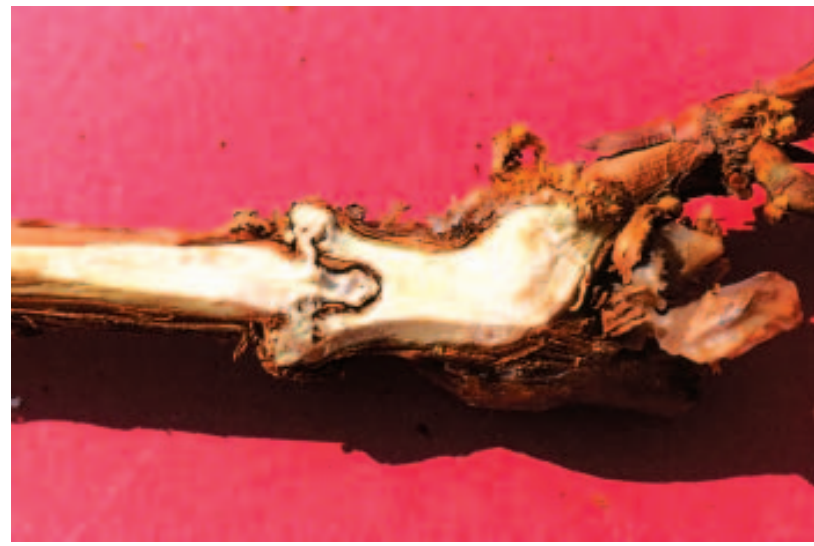

Fig. 2. Black streaks appearing in longitudinal section extending upwards from the basal end of a 1103 Paulsen rootstock.

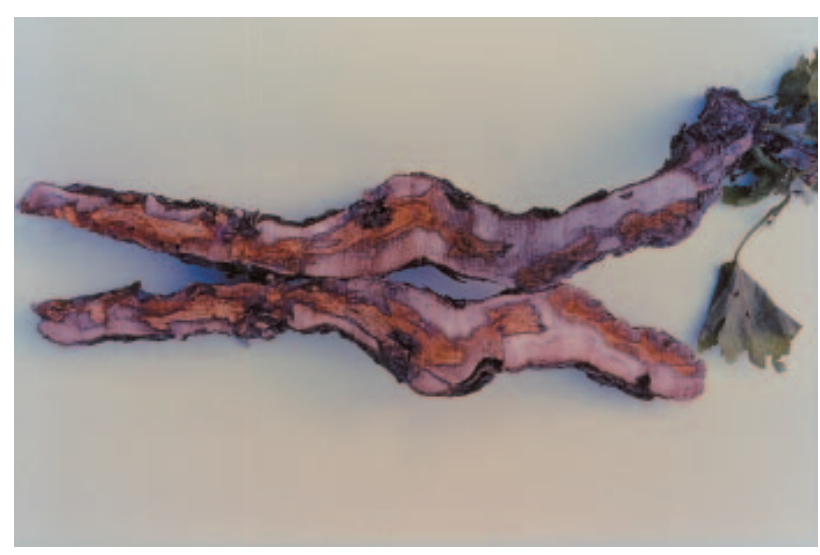

Fig. 4. Classical wood necrosis of esca in a cross sectional cut of a cv. Roditis rootstock.

the high incidence of Fomitiporia punctata in diseased vines $>10$ year old (Table 1 ). In the other vines studied, although pathogenic fungi were present, the incidence was so low that the cause of any decline could not be attributed solely to any of them. Discolored wood may be derived from poor nursery practices or from lesions caused during preparation.

In conclusion, in Greek grapevines there are at least two causes of vine decline: a) white rot caused by Fomitiporia punctata or other wood-rotting fungi in the older vineyards (esca proper), and b) poor planting material in newly established vineyards associated with different fungi such as $P$. chlamydospora, Phaeoacremonium spp., Botryosphaeria spp. and Cylindrocarpon spp. which colonize the scion or the 
rootstock in the nurseries. Vines affected by woodrotting fungi could be also colonized by one or more fungi from the nurseries, and vice versa. The same phenomenon is also observed with Eutypa lata, which often develops together with $F$. punctata in the same trunk, and even in the same cross-section of a trunk.

\section{Literature cited}

Barnett H.L., 1960. Illustrated genera of imperfect fungi. Burgess Publishing Company, Minneapolis, USA.

Bertelli E., L. Mugnai and G. Surico, 1998. Presence of Phaeoacremonium chlamydosporum in apparently healthy rooted grapevine cuttings. Phytopathologia Mediterranea 37, 79-82.

Chicau G., M. Aboim-Inglez, S. Cabral and J.P.S. Cabral, 2000. Phaeoacremonium chlamydosporum and Phaeoacremonium angustius associated with esca and grapevine decline in Vinho Verde grapevines in northwest Portugal. Phytopathologia Mediterranea 39, 80-86.

Crous P.W. and W. Gams, 2000. Phaeomoniella chlamydospora gen. et comb. nov., a causal organism of Petri grapevine decline and esca. Phytopathologia Mediterranea $39,112-118$.

Crous P.W., W. Gams, M.J. Wingfield and P.S. van Wyk, 1996. Phaeoacremonium gen. nov. associated with wilt and decline diseases of woody hosts and human infections. Mycologia 88, 786-796.

Erkan Ari M., 2000. A general approach for esca disease in the vineyards of Turkey. Phytopathologia Mediterranea 39, 35-37.

Ferreira J.H.S., 1999. Researching Phaeoacremonium in rootstocks: summary, highlights and excerpts. In: Black gooSymptoms and Occurrence of Grapevine Declines. IAS/ ICGTD Proceedings 1998 (L. Morton, ed.) International Ampelography Society, Fort Valley, VA, USA, 94-97.

Ferreira J.H.S., P.S. Van Wyk and E. Venter, 1994. Slow dieback of grapevine: association of Phialophora parasitica with slow dieback of grapevines. South African Journal of Enology and Viticulture 15(1), 9-11.

Ferreira J.H.S., P.S. Van Wyk and F.J. Calitz, 1999. Slow dieback on grapevine in South Africa: stress-related predisposition of young vines for infection by Phaeoacremonium chlamydosporum. South African Journal of Enology and Viticulture 20(2), 43-46.

Graniti A., G. Surico and L. Mugnai, 2000. Esca of grapevine: a disease complex or a complex of diseases? Phytopathologia Mediterranea 39, 16-20.

Koklu G., 2000. Notes on esca disease on some grapevine varieties grown in Turkish Thrace. Phytopathologia Mediterranea 39, 38-40.

Larignon P. and B. Dubos, 1997. Fungi associated with esca disease in grapevine. European Journal of Plant Pathology 103, 147-157.
Larignon P. and B. Dubos, 2000. Preliminary studies on the biology of Phaeoacremonium. Phytopathologia Mediterranea 39, 184-189.

Larignon P. and B. Dubos, 2001. Le black dead arm. Maladie nouvelle à ne pas confonde avec l'esca. Phytoma 538, 26-29.

Morton L., 1995. Mystery diseases hit young vines. Wines and Vines 76, 46-47.

Morton L., 1997. Update on black goo. Wines and Vines 78 (1), 62-64.

Morton L., 1999. On the trail of black goo. In: Black gooSymptoms and Occurrence of Grapevine Declines. IAS/ ICGTD Proceedings 1998 (L. Morton, ed.), International Ampelography Society, Fort Valley, VA, USA, 56-77.

Mugnai L., G. Surico and A. Esposito, 1996. Micoflora associata al mal dell'esca della vite in Toscana. Informatore fitopatologico 46(11), 49-55.

Mugnai L., A. Graniti and G. Surico, 1999. Esca (black measles) and brown wood-streaking: two old and elusive diseases of grapevines. Plant Disease 83, 404-418.

Pascoe I.G., 1999. Grapevine trunk diseases in Australia: diagnostics and taxonomy. In: Black goo-Symptoms and Occurrence of Grapevine Declines. IAS/ICGTD Proceedings 1998 (L. Morton, ed.), International Ampelography Society, Fort Valley, VA, USA, 56-57.

Pascoe I.G. and E. Cottral, 2000. Developments in grapevine trunk diseases research in Australia. Phytopathologia Mediterranea 39, 68-75.

Rego C., A. Carvalho, T. Nascimento and H. Oliveira, 2001. First approach on the understanding of inoculum sources of Cylindrocarpon destructans and Phaeomoniella chlamydospora concerning grapevine rootstocks in Portugal. In: IOBC Meeting Working Group "Integrated Control in Viticulture”, 3-7 March 2001, Lisbon Portugal, 51-52 (abstract).

Rumbos I., 1986. Phialophora parasitica, causal agent of cherry dieback. Journal Phytopathology 117, 283-287.

Rumbos I., 1987. Twig and branch dieback of walnut trees induced by Botryosphaeria ribis. Plant Pathology 36, 602-605.

Rumbos I., 1995. Diseases and pests of grapevine. 4th edition. ORES Publishing, Volos, Greece, 280 pp. (in Greek).

Rumbos I., 2000. Young grapevine decline caused by Phaeoacremonium spp. and Cylindrocarpon spp. In: 10th Panhellenic Phytopathological Congress, 3-5 October 2000, Kalamata, 85 pp. (abstract, in Greek).

Scheck H., S. Vasquez, D. Fogle and W.D. Gubler, 1998. Grape growers report losses to black foot and grapevine decline. California Agriculture 52, 19-23.

Whiting E.C., A. Khan and W.D Gubler, 2001. Effect of temperature and water potential on survival and mycelial growth of Phaeomoniella chlamydospora and Phaeoacremonium spp. Plant Disease 85, 195-201.

Zachos D.G., 1960. First observations on a chronic disease of the grapevine. Annales de l'Institut Phytopathologique Benaki N.S. 3, 121-122. 